Royal Botanic Gardens, Kew : Dr. N. L. Bor, C.I.E.

Dr. Norman Loftus Bor, who was recently appointed assistant director of the Royal Botanic Gardens, Kew, had a distinguished career at Trinity College, Dublin, and the University of Edinburgh, and was awarded his doctorate for a thesis on the "Synecology of the Naga Hills". He has had wide experience in forest and general administration in the Indian Forest Service during 1921-46. He was political officer of the Balipara Frontier Tract during 1931-34, deputy commissioner of the Naga Hills in 1935 and acting inspector-general of forests in 1939. During 1942-46 he held a responsible position in relation to evacuation, reconstruction and rehabilitation on the North-East Frontier. $\mathrm{H}_{\Theta}$ has travelled extensively in India and the Near East. During 1937-42 he was forest botanist at the Forest Research Institute, Dehra Dun, and in recent years has carried out research on the Indian species of the Gramineæ. Dr. Bor's published botanical works deal with the taxonomy of Indian plants and with the ecology of Assam and the Nilgiri Hills. In particular, he has concentrated on the study of grasses and has described new species from various parts of India. Recently, at Kew, he has made a detailed study of the Indian species of Poa.

National Museum of Wales: Sir Cyril Fox, F.B.A.

IT is sad to realize that the time has come for Sir Cyril Fox to retire from the post of director of the National Museum of Wales. The old saying may be true, "Le roi est mort, vive le roi", but his successor will find it no light matter to continue Sir Cyril's distinction as a researcher and his efficiency as an administrator. Fox was educated at Christ's Hospital and Cambridge. He was always an ardent archæologist, even in the days of long ago (1912--24) when at Cambridge he occupied the post of superintendent of the University Field Laboratories. Indeed it was at this time that his great work, "The Archæology of the Cambridge Region", which gained him his Ph.D., was written and published, and that he did so much splendid voluntary work for the Cambridge Museum of Archæology and Ethnology, where his beautiful lettering on the labels of things he arranged is still admired. In 1924 he was elected a Kingsley Bye-Fellow of Magdalene College, and later-after his nomination to the directorship of the National Museum in Dublin by the Irish Academy had been refused by the then Irish Civil Service on the grounds that he was an Englishman-he became a keeper and lecturer in the National Museum of Wales, of which he was soon to become the director. Sir Cyril has, not unnaturally, been president of a number of archæological societies, and has published regularly the results of his researches. His most thought-productive work, perhaps, has been "The Personality of Britain", which has passed through no less than four editions. There are other archæologists who can claim a high degree of scholarship and achievement, but few who can inspire and charm as does Sir Cyril Fox; to be with him is indeed an inspiration. The best wishes of all go to him in his retirement at Exeter, where his wife is lecturing and where we may be sure he will have retired only from administration, and will doubtless pursue his researches with continued zest and a freer mind.
Mr. D. Dilwyn John

Mr. David DILWYN John, who is succeeding Sir Cyril Fox as director of the National Museum of Wales, is a graduate of the University of Wales. He served as a zoologist on the staff of the Discovery Investigations during 1925-35, making three voyages to the Antarctic, and was later awarded the Polar Medal. In the course of one of these commissions, while he was in charge of the scientific work, the first winter circumnavigation of the southern continent was made. His researches into the development and distribution of southern Euphausiidæ, based on material much of which he had himself collected, resulted in a report which is a fundamental contribution to our knowledge of the natural history of these important Antarctic crustaceans. On appointment to the British Museum (Natural History) in 1935, Mr. John was put in charge of the collections of Echinoderms, and his principal publications in recent years have been related to the subject of his specialization. In particular, he has concentrated on collections of Crinoidea made by such expeditions as the Discovery, Scotia, Belgica and the British, Australian and New Zealand Antaretic Expedition in high latitudes, and besides the taxonomic results obtained, themselves of great value, he has thrown much interesting light on viviparity in the Crinoidea and the care of the brood by the parent animal. A Territorial Army officer prior to the War, he was on military service until 1946; he became a deputy keeper in the Department of Zoology in February of this year.

\section{World Co-operation in Science}

Prof. J. D. Bernal's recent presidential address to the Association of Scientific Workers contains some points which merit the notice and support of all scientific workers. He directed attention to the danger which retarded capital expenditure involves to industrial development and research, and also to the consequences to scientific effort if the reconstruction plans of the universities and research laboratories should be curtailed or postponed. $\mathrm{He}$ emphasized that neglect and waste of resources, both material and human, continue, and quoted Sir Henry Tizard's statement to the Parliamentary and Scientific Committee that on existing knowledge productivity could be raised by fifty per cent. As he very truly remarked, the hope of Great Britain, economically, culturally and scientifically, lies in the extent of its links with all other countries, with the United States no less than with Soviet Russia, with Eastern no less than Western Europe, and with the Colonial peoples. The world requires the flourishing of science as a basic condition of human happiness, even of human life itself; but scientific men by themselves form a weak minority, and can only be effective if they associate themselves with all others who have a common will for reconstruction and peace. Much of Prof. Bernal's address, however, was an attack on the Marshall plan for aid to Europe and the Government's policy of removing communists from key positions in defence research which ignores both the totalitarian threat to the freedom of science in Soviet Russia and the question of loyalties which has compelled Government action in Britain against communists. 